UNRAM Law Review is licensed under a Creative Commons Attribution 4.0 International License, which permits unrestricted use, distribution, and reproduction in any medium, provided the original work is properly cited. p-ISSN: 2548-9267 | e-ISSN : 2549-2365, Open Access at : http://unramlawreview.unram.ac.id/index.php/ulr

\begin{tabular}{c|c|c|c|c|}
\hline Volume & Issue & Page & October & p-ISSN: 2548-9267 \\
\hline 4 & 2 & $98-111$ & 2020 & e-ISSN : 2549-2365
\end{tabular}

\title{
Realizing Justice through the Credit Restructuring Policy Due to the Spread of Covid-19
}

\author{
Josua Navirio Pardede \\ Master in Legal Science Program, Faculty of Law, Gadjah Mada University \\ Jl. Sosio Yustisia No. 1, Bulaksumur, Kab. Sleman, D.I. Yogyakarta 55281 -Indonesia \\ Email: josuanavirio1996@gmail.com \\ Wigati Taberi Asih \\ Master in Legal Science Program, Faculty of Law, Gadjah Mada University \\ Jl. Sosio Yustisia No. 1, Bulaksumur, Kab. Sleman, D.I. Yogyakarta 55281 -Indonesia \\ Email:wigatita@gmail.com
}

\begin{abstract}
This study aims to find an overview of the bank credit restructuring policy and the realization of the fair value of the government policy. The stimulus provided was in the form of restructuring bank credit due to the spread of Covid-19. The research method used is a normative juridical research method with a statutory approach and a conceptual approach. This study uses secondary legal data in the form of primary legal materials, namely POJK No. 11 / POJK.03 / 2020, and secondary legal materials, namely books, journals, and other literature related to research problems. Based on the results of the study, it is known that the credit restructuring policy is an attempt by the government to provide legal protection for bank debtors who cannot fulfill their obligations to banks due to the spread of Covid-19. The realization of the value of justice in this credit restructuring policy is felt by all parties, the bank, and especially the debtor. The existence of a bank credit restructuring policy guarantees legal certainty to provide a sense of justice for debtors affected by Covid-19.
\end{abstract}

Keywords: Credit Restructuring Policy; Justice, Utility; Certainty.

\section{INTRODUCTION}

The world is being hit by a global pandemic caused by Covid-19 (Corona Virus Disease 2019). Based on data from WHO (World Health Organization), as of May $20^{\text {th }}, 2020$, there were 4,789,205 Covid-19 cases with 318,789 deaths worldwide, including Indonesia. ${ }^{1}$ With the number of cases that has reached 20,162 with 1278 deaths, Indonesia became the second ranked country in Southeast Asia with the highest number of Covid-19 cases. ${ }^{2}$

This critical situation forced the government to issue a number of policy packages to achieve its main mission of resolving the Covid-19 outbreak in Indonesia. From central to regional regulations as well as president or ministerial-level regulations and various

\footnotetext{
${ }^{1}$ World Health Organization. (2020). Coronavirus Disease (Covid-19) Situation Report-121, <https://www.who.int/ emergencies/diseases/novel-coronavirus-2019/situation-reports $>$. accessed 20th May 2020.

2 Gugus Tugas Percepatan Penanganan Covid-19, Situasi Virus Covid-19 Di Indonesia. 2020 <https://doi.org/DOI: http://dx.doi.org/10.30649/htlj.v3i2.128>. accessed 20th May 2020.
} 
other legal instruments have been issued to ensure the success of law enforcement during this outbreak ${ }^{3}$.

One of the regulation which government created, particularly by OJK (Otoritas Jasa Keuangan / Financial Service Authority) trying to preserve economy sector especially in banks sector by issuing a new regulation on restructuring for affected debtors due to Covid-19 disease under "Peraturan Otoritas Jasa Keuangan No. 11/POJK.03/2020 about National Economic Stimulus as a Countercyclical Impact Policy due to Spread of Coronavirus Diseases 2019”. This regulation issued and effective on March, $16^{\text {th }}$ 2020. The basis reason of this regulation is for protecting the bank from the affected debtors who cannot fulfil their installment as their business is affected by the spread of Covid-19. Therefore, this condition will affect bank's performance and financial system stability which influence economic growth. For encourage optimization of intermediation bank function, maintain the stability of financial, and support economic stability, this regulation is becomes a necessity. In addition, the Bank also plays an important role in economic activities, encouraging national development and creating public welfare. $^{4}$

The affected debtors in this regulation are the micro, small, and medium enterprise debtors whose business in tourism, transportation, hotel, trading, processing, agriculture, and mining, both direct or indirectly is affected due to the spread of Covid-19 and the debtors who facing difficulty in fulfills their installments caused of this critical situation. Hence, government provide a special treatment in this POJK, a restructuring mechanism that can be applied to debtors who have business other than tourism, transportation, hospitality, trade, processing, agriculture, and mining sectors as long as the bank's self-assessment shows that the debtor is affected by COVID-19. Based on data, there are 3.88 millions debtors who propose restructuring in the banking industry and its nominal reach out Rp336,97 trillion. ${ }^{5}$ The amount of debtors who proposed restructuring and the restructurisation's amount represent the high number of restructuring submissions. Hence, the discussion on this issue is still contextual with Indonesia's current condition.

The high number that shown by previous data, is an effect from the issue of POJK No.11/2020 that is still valid until March, 31st 2021. This regulation applies for Conventional Bank, Syariah Bank, Rural Credit Bank, and Syariah Rural Credit Bank. The purpose of this regulation is to encourage the optimization of banking performance especially the intermediation function, maintain financial system stability, and encourage economic growth amid this pandemic.

From a broader perspective, particularly from the legal abstraction realm, the restructuring mechanism is closely related to the construction of justice, certainty and utility/purposiveness value of law as a form of responsive action against the current epidemic conditions. In order to comprehend these construction, it is becomes a necessary to analyze the ability of this regulation in creating an ideal and proportional nuance of law in the middle of this unpredictable situation.

As explained by Rahardjo, the principles or basic values of law are the "heart" of a legal regulation, then, an ideal process of understanding some rules is not only by reading clausula

\footnotetext{
${ }^{3}$ Kornelius Benuf Samuel Arsheldon, Supriardoyo Simanjuntak. (2020). 'Strategi Antisipasi Over Kapasitas Lapas Suatu Refleksi Atas Kebijakan Pencegahan Penyebaran Covid-19', ADLIYA: Jurnal Hukum Dan Kemanusiaan, 14.(1):1-26.

4 Darminto Hartono Paulus Herdian Ayu Andreana Beru Tarigan. (2019). 'Protection of Customers For Management of Digital Banking Services (Study at PT. BRI Unit Boyolali)', Hang Tuah Law Journal, 2.(2): 170-179.

5 Dewa Ketut Sudiarta Wiguna/ (2020), OJK: Restrukturisasi Kredit Dampak COVID-19 Tembus Rp336,97 Trili un, $<$ https://www.antaranews.com/berita/1483840/ojk-restruk t urisasi-kredit-dampak-covid-19-tembus-rp33697-trili un>. accessed on 28th May 2020.
} 
that written on it, but also by looking into the basic principles or values that build those regulation. ${ }^{6}$ The philosophical concept of legal basic values itself comes from Radbruch's notion that combine dialectically the central theses of traditional natural law theory and legal positivism, constructing 3 basic legal values consisting of justice (Gerechtigkeit), certainty (Rechtssicherheit) and purposiveness/utility (Zweckmassigkeit). ${ }^{7}$

However, the main component on these three basic values of law are not an original concept derived from Radbruch's idea, yet it existed way before the notion of tension between those three values or spannungverhaltniss proposed.

The concept of justice, for example, has been an idea debated since ancient Greece by platonic philosophers and became a vital organ on the philosophy of law. Nevertheless, as stated by Tebbit, "The concept of justice is not only the most prominent theoretical concept in the philosophy of law, equalled in importance only by that of 'law' itself, it is also so regular a feature of common discourse about public life that virtually everybody has an immediate intuitive understanding of it". ${ }^{8}$ This argument shows that the discourse between justice and law has becomes an urgency. Hence, the relationship between this two subject has become an ideal picture expected by the public towards the law itself. In this case, regulation on banking restructuring mechanisms as a legal instruments are expected to reflect the ideas of justice that are contained therein.

Another basic value, utility/beneficial, is an idea derived from the notion of a English philosopher and jurist in the 18th century, Jeremy Bentham. The idea that also known as "Bentham's principle of utility", is generally understood to require that each of us always serve "the greatest happiness". However, this concept still considered to contain a lot of blunder/ mistakes, as related to his view on human nature in the construction of the utilitarian principle, implies that it is impossible for humans to do things that his principle of utility requires human to do, such as sacrifice of man own happiness for the sake of others. Hence, this substance violates the fundamental principle of "ought implies can" that Bentham already argue before. 9

Nevertheless, this notion is still considered important and has an impact on the renewal of thought in the social, political and legal fields. Therefore, it continues to be developed by several subsequent utilitarian thinkers such as John Stuart Mill, who stated that, "It is quite compatible with the principle of utility to recognize the fact, that some kinds of pleasure are more desirable and more valuable than others. It would be absurd that while, in estimating all other things, quality is considered as well as quantity, the estimation of pleasures should be supposed to depend on quantity alone". ${ }^{10}$ From the standpoint of this argument, the concept of utilitarianism tends to look more at the qualitative aspect, contrast with Bentham's argument which focuses on the quantitative aspect.

On the legal science realm, legal certainty, is understood as a condition in which law can provide the existence of concrete strengths for the law in question. The existence of the principle of legal certainty is emphasize on the protection of justiciable (justice seekers) against

\footnotetext{
${ }^{6}$ Satjipto Rahardjo. (2014). Ilmu Hukum. Bandung: Citra Aditya Bakti, p. 65.

${ }^{7}$ Heather Leawoods. (2000). 'Gustav Radbruch: An Extraordinary Legal Philosopher', Washington Universiy Journal of Law \& Policy, 2.(1), p. 489.

8 Mark Tebbit. (2017). Philosophy of Law: An Introduction. New York: Routledge, p.6.

9 David Lyons. (2003). In the Interest of the Governed: A Study in Bentham's Philosophy of Utility and Law. New York: Oxford University Press, p. 12.

10 John Stuart Mill. (1998). Utilitarianism. London: Oxford University Press, p. 56.
} 
a despotic action, which means that a person will and able in obtain something that is expected under certain circumstances. ${ }^{11}$

Without legal certainty, people do not understand the actions that should be taken, and finally there is uncertainty which results in chaos due to the indecisiveness of the legal system. Therefore, the legal certainty refers to the implementation of clear, permanent and consistent law in which its implementation cannot be influenced by subjective circumstances. ${ }^{12}$ As a basic value, legal certainty has become a major component that must be constructed by law through its existing legal instruments. Based on the description above, there are two problems to be discussed in this study, namely; first, how is the bank credit restructuring policy as a Countercyclical Mechanism for Indonesia's Covid-19 Policy, the second problem is how to construct the value of justice, certainty and benefit in the system of providing financial stimulus in the form of bank credit restructuring.

\section{METHOD}

This paper uses the normative/doctrinal legal research method ${ }^{13}$, a legal research method that portrays law as a prescriptive discipline, which only looks at the law from the point of view of its norms. ${ }^{14}$ In accordance with the normative character, this paper is part of a framework of normative discussion themes, such as research on legal principles and legal system. ${ }^{15}$ In constructing its analysis, this paper uses secondary data, particularly library research, which aims to gather information from books, journals, articles, and other legal documents. ${ }^{16}$

\section{ANALYSIS AND DISCUSSION}

\section{Brief Explanation on Banking Credit Restructuring as a Countercyclical Mechanism on Indonesia's Covid-19 Policy}

Based on POJK No.11/2020, the debtors who could submit the restructuring policy are the affected debtors, being affected by the outbreak and experiencing financial difficulties due to the impact of the Covid-19 outbreak. The debtors are micro, small and medium enterprises whose business in tourism, transportation, hotel, trading, processing, agriculture, and mining that are affected directly or indirectly by Covid-19. However, there is a special treatment in this POJK, namely that restructuring can be applied to debtors who have business other than tourism, transportation, hospitality, trade, processing, agriculture, and mining sectors as long as the bank's self-assessment shows that the debtor is affected by COVID-19. Therefore, banks must have guidelines that at least explain the criteria for debtors determined to be affected by

\footnotetext{
${ }^{11}$ Sudikno Mertokusumo. (1993). Bab-Bab Tentang Penemuan Hukum. Bandung: Citra Aditya Bakti, p. 2.

12 R. Tony Prayogo. (2016). 'Penerapan Asas Kepastian Hukum Dalam Peraturan Mahkamah Agung Nomor 1 Tahun 2011 Tentang Hak Uji Materiil Dan Dalam Peraturan Mahkamah Konstitusi Nomor 06/PMK/2005 Tentang Pedoman Beracara Dalam Pengujian Undang-Undang', Jurnal Legislasi Indonesia, 13.(2), p. 194.

${ }^{13}$ Kornelius Benuf and Muhamad Azhar, (2020), 'Metodologi Penelitian Hukum Sebagai Instrumen Mengurai Permasala han Hukum Kontemporer', Gema Keadilan, 7.(1), p. 20-33.

${ }^{14}$ Depri Liber Sonata. (2014). 'Metode Penelitian Hukum Normatif Dan Empiris Karakteristik Khas Dari Metode Meneli ti Hukum', Fiat Justisia Jurnal Ilmu Hukum, 8.(1), p. 26.

${ }^{15}$ Sri Mamudji Soerjono Soekanto. (2001). Penelitian Hukum Normatif; Suatu Tinjauan Singkat, Jakarta: Raja Grafindo Persada.

${ }^{16}$ Depri Liber Sonata, p. 31-32.
} 
COVID-19 and the affected sectors. This restructuring could be apply on debtors who loan before or amid Covid-19 and doesn't have any limitations.

Based on Bank Indonesia regulation No. 14/15/PBI/2012, credit restructuring is an effort to improve Banks in lending activities to debtors who having difficulty to fulfill their obligations, which is through: ${ }^{17}$
a. Reduction in loan interest rates;
b. Extension of the credit period;
c. Reduction of interest arrears on credit;
d. Reduction of principal loan arrears;
e. Additional credit facilities; and/or
f. Credit conversion to temporary equity participation.

The basic principle of restructuring mechanism is located on the current condition of the debtors. Are the debtors should be the debtors (micro, small, medium enterprise debtors) whose business experience difficulty because of the spread of Covid-19 and the debtors that could not fulfil their obligation for pay back their installment ${ }^{18}$.

Furthermore, POJK No. 11/2020 explained the mechanism restructuring are:

a. Credit for Conventional Bank held based on OJK regulation about assessment the asset quality of conventional bank;

b. Financing for Syariah Bank and UUS is held based on the OJK regulation about assessment the asset quality of Syariah Bank and UUS;

c. Credit for Rural Bank is held based on OJK regulation about the quality of productive asset and the allowance for possible losses on earning assets;

d. Financing for Rural Bank Syariah is held based on OJK regulation about the quality of productive assets and the allowance for possible losses on earning assets Islamic people's finance bank;

e. Credit conversion to temporary equity participation.

Credit restructuring is held based on this POJK about asset quality assessment, through: ${ }^{19}$

a. Interest rate reduction;

b. Extended time;

c. Reduction of principal arrears;

d. Reduction of interest arrears;

e. Addition of credit/financing facilities; and/or

f. Credit/financing conversion to Temporary Equity Participation.

These schemes depend not only in the banks, but also the result of bank identification of the debtor's financial performance or the assessment of the business prospects and the capacity of the debtors to fulfil the installment who are affected by Covid-19. The period of this restructuring has a various model depending on the bank assessment of the debtors with maximum term of one year.

The quality of the credit which is being restructured could be determined if its restructuring is given for the debtors who identified as the debtors who affected the spread of Covid-19.

\footnotetext{
${ }^{17}$ Otoritas Jasa Keuangan. (2020). Frequently Asked Questions: Restrukturisasi Kredit Pembiayaan Terkait Dampak COVID-19, accesed on 29th May 2020

${ }^{18}$ Reky Nurviana Ashinta Sekar Bidari. (2020). 'Stimulus Ekonomi Sektor Perbankan Dalam Menghadapi Pandemi Coro navirus Disease 2019 Di Indonesia', Legal Standing Jurnal Ilmu Hukum, 4.(1), p. 302.

${ }^{19}$ Otoritas Jasa Keuangan.
} 
Through this policy, OJK gave the independence to the bank in prescribing the restructuring, however, according to POJK as a main regulation on providing restructuring mechanism for debtors, particularly in asset quality assessment.

The scheme of restructuring or the application of it could be various and depend on the bank's policy. Indeed, banks would like to assess the profile and the capacity of debtors for paying back their loans. OJK emphasizes that each bank should be responsible and prevent moral hazard in case the bank applied this restructuring policy ${ }^{20}$. OJK through this policy hopes that this regulation will be applied as well as the bank and the debtors need, not be used for irresponsible parties. Hence, this policy notably issued for the debtors and their business that affected by Covid-19, not for the debtors who previously have a problem in fulfilling their installment before outbreak and gain a benefit due to this regulation. Moreover, as an ideal bank, it should avoid this occurrence which is called a moral hazard.

\section{The Construction of Justice, Certainty and Utility on the Banking Credit Restructuring Policy}

The ideal legal construction will always stand from three main values namely justice, certainty and expediency. Not only in the abstract domain, these three values must strive to be realized and can be felt by the public, through existing legal instruments, in this case the bank credit restructuring policy.

\section{The Construction of Legal Justice Through Banking Credit Restructuring Policy}

Justice is one of the main and essential elements that must be possessed in a legal policy. The importance of justice in legal products can be understood as described by John Rawls, who explains that, "A theory however elegant and economical must be rejected or revised ifit is untrue; likewise laws and institutions no matter how efficient and well-arranged must be reformed or abolished if they are unjust". ${ }^{21}$ This statement is a classic concept that can be understood related to justice and its relationship with a legal policy that will be construct.

The banking credit restructuring policy that contained in POJK No.11/2020 also must have an aspect of justice that will be created through its policy. Based on the analysis in the previous discussion, aspects of justice in this policy can be seen from several principles and clauses set forth therein.

The inclusion of the justice aspect on the banking credit restructuring policy is manifested in proportional and ideal structuring of the mechanism and position for debtors and creditors during the outbreak.

There are 2 main essence of justice in this policy. The first one is this legal instrument is a form of sensitivity to the condition of the Covid-19 outbreak as a variable that needs to be responded specifically by law. The situation of the Covid-19 epidemic has resulted in a holistic change in almost all aspects of life, and this has influenced the shift in the concept of ideal justice in society, especially in the economic sector. Thus, the responsiveness of legal

\footnotetext{
${ }^{20}$ Himawan Sutanto, Hanif Nur Widhiyanti, and Istislam. (2018). 'Legal Protection Against Banks As A New Creditural Candidate In Take Over Credit Process', Unram Law Review, 2.(2), p. 126-40 <https://doi.org/DOI: https://doi. org/10.29303/ulrev.v2i2.45>.

${ }^{21}$ John Rawls. (1971). A Theory of Justice. London: Harvard University Press, p. 3.
} 
institutions through the banking credit restructuring policy tries to reorganize the new order of justice during this epidemic.

Secondly, the form of justice that will be constructed is related to the mechanism of this policy that trying to place the two parties, namely creditors and debtors proportionally in new conditions during the epidemic. This policy does not only focus on one party, yet both as a form of healthy economic sector interaction.

Banks as creditors are required to follow a number of provisions aimed at providing a fair position for both parties, one of this provisions is through the obligation of a proactive attitude towards the debtor.

OJK through this regulation asked banks to proactively help their debtors by offering the exactly restructuring schema to the debtors about this new regulation, for example in aspects of time period, the amount of installments and relaxation of interest.

The construction of justice was further realized through the existence of the prudential banking principle, a principle which being compulsory guideline and must be adhered consistently in the banking industry to actualize a healthy, tough, and efficient based on the regulation, the explanation of article 2 in legislative regulation No. 21/2008 on Syariah Bank. In all of the regulations in Indonesia, there is no explanation about the meaning of prudential banking principle.

Prudential banking principle is a principle for protecting financing from any problems by identify the customer through identify the identity of the customer, the customer's document information, and others. ${ }^{22}$ This principle shows that the position of banks in this policy is still considered and placed proportionally.

The existence of these principles seeks to balance the conflict between substantive justice and procedural justice contained in this policy. Substantive justice which originates from the philosophy of idealism will always conflict with procedural justice with its positivist. ${ }^{23}$ Although they do not try to eliminate the contradictions within them, the principles attempt to show that the banking credit restructuring policy provides a tool to establish justice as a constitutive element of law.

As Huijbers stated, the reason why justice is a constitutive element of law is: ${ }^{24}$

a. The government of any country always defends action by showing real justice in it

b. Laws that are not in accordance with the principles of justice are often regarded as laws that are outdated and no longer valid.

c. By acting unjustly, a government actually acts outside its unlawful authority according to law

Hence, the two main aspects of justice that have been discussed above already become the basis of the value of justice that can be found in the core of this regulation, both technical and idealistic in character.

Nevertheless, justice is one of those concepts - like 'being' or 'truth'-that is so readily understood, especially in the context of its negation, 'injustice', that any questioning of its

${ }^{22}$ Vaithzal Rivai. (2008). Islamic Financial Management: Teori Konsep Dan Aplikasi Panduan Praktis Untuk Lembaga Keuangan, Nasabah, Praktisi Dan Mahasiswa. Jakarta: Kharisma Putra Utama Offset, p. 617.

${ }^{23}$ Munir Faudy. (2005). Filsafat Dan Teori Hukum Posmodern. Jakarta: Kompas, p. 39.

${ }^{24}$ Theo Huijbers. (1991). Filsafat Hukum Dalam Lintasan Sejarah, Yogyakarta: Kanisius, p. 70. 
meaning tends initially to cause consternation. So the analysis of the value of justice in this policy will be clearer if it can see the potential of injustice that can occurred.

The unjust possibility can be analysis is by looking at the sustainability of the objectives of this policy, especially in relation to the situation that exists after the pandemic ends or the expiration of regulations.

One of this is a policy regarding on the reducing principal repayment and charging the remaining installment payments to be paid after the outbreak ends. The main point that need to be highlighted here is whether the debtor is able to pay the remaining installments or not? This is a prominent issue, as if it does not get further guarantees, this policy will only be partial and not provide a sustainable justice after the end of the policy.

Based on this, it is necessary to have an additional special policy for debtors who experiencing credit deficiency, so that debtors do not experience difficulties in meeting the installment amount. This procedural issue have a lot of impact on the construction of sustainable justice or if it not going well, unjust will take a place.

\section{The Construction of Legal Certainty through Banking Credit Restructuring Policy}

The legal certainty value is a basic principle that is stand inside the flow of positivist reasoning. As stated by Anshori, positivism is a scientific attitude that rejects a priori speculations and tries to build itself on more materialistic experience data. ${ }^{25}$ Although it has not yet given a concrete description of the legal certainty concept, this understanding shows an analysis scheme that results in the legal certainty value.

Positivist philosophy not only provides basic reasoning related to the value of legal certainty, but also provides that value with a clear purpose. The absolute mission of legal certainty is to achieved an order in protect the public interest (which includes personal interests) by functioning as the main justice enforcer in society (order), upholding the confidence of citizens in the authorities (government), and upholding the authority of the authorities before the views of citizens. ${ }^{26}$ Hence, legal certainty can be understood as a value that guarantees that a rule can be carried out and enforced, without any idealistic-subjective intervention that has an impact on changing the implementation character of law.

The value of legal certainty that underlies this policy can be seen from the main ideas that seek to provide certainty to credit payments on the uncertain times of pandemic.

Article 2 (1) \& (2) of POJK No. 11/2020 provide certainty for debtors who are constrained by credit payments due to their business being affected by the plague followed by certainty for banks as creditors through the entire clause on article 2 .

Thus, these rules also provide legal certainty for banks regarding the mechanism of restructuring implementation, whereby POJK No. 11/2020 provides legitimacy that gives authority to bank in perform the restructuring mechanism in accordance with the policies of each bank as long as it follows the prudential principle of the bank and avoids moral hazard, which prevent this restructuring policy to be utilized by the free riders (inappropriate users).

\footnotetext{
${ }^{25}$ Abdul Ghofur Anshori. (2016). Filsafat Hukum Sejarah, Aliran dan Pemaknaan. Yogyakarta,: Gadjah Mada University Press, p. 92.

${ }^{26}$ Ridwan Halim. (1987). Evaluasi Filsafat Hukum. Jakarta: Ghalia Indonesia, 1987, p. 166.
} 
Technically, the value of legal certainty can also be seen from a number of other clauses such as interest rate reduction, extension of the credit period, reduction of arrears on loan interest, additional credit facilities dan credit/financing conversion to temporary equity participation.

The period of restructuring for 12 months or 1 year until March 31, 2021 becomes the certainty of the policy period and consideration of the construction of the new certainty after the expiration of the POJK No. 11/2020 POJK.

In providing credit, bank should adhered the prudential banking principle thorough analyze the 5C (Character, Capability, Capital, Collateral, and Condition of Economy) principle as a commitment to legal certainty in the selection process of affected debtors. The assessment with $5 \mathrm{C}$ principle consist of:

\section{Character}

Trustworthy is the main nature or character of the people who will receive credit from bank. To analyze the nature or character of the debtors, bank need to find out the background of the prospective debtor. By understand it, bank will able to measure the "willingness" of customers to pay their debts. ${ }^{27}$

Bank needs to analyze the character of the candidate customer in order to find out that the candidate customer has a willingness/desire to repay the finance which they received. Bank need to convinced the willingness of the prospective debtors to fulfill their obligations in accordance with the agreed time period. ${ }^{28}$

The assessment of the prospective debtor who will receive the credit facility is mainly based on the relation that exist between syariah bank or syariah business unit and the customer or prospective debtors or the information that received from other person who assured. The syariah bank and syariah business unit can conclude and decide which candidate customer who will receive the credit facility based on honest, good faith, and will not complicate the syariah bank and syariah business unit in the future. ${ }^{29}$

The methods which could be done by banks for identifying the character of the candidate of the customer: ${ }^{30}$

1. Examination by Central Bank of Indonesia/Bank Indonesia

Bank analyzes the candidate of the customer by reviewing the customer's data through the online database system which is related to Bank Indonesia.

2. Information from other parties

Bank analyzes the candidates of the customer through other parties who are well-known to the candidates of the customer. For instance, seeking for the information about the candidate of the customer's character through their neighbor, their colleagues, their boss, and their co-partner business.

\section{Capacity}

To find out the capacity of prospective borrowers, banks can obtain it in various ways. For example to the known customer, the bank can analyze the documents, files, archives and records that exist about their previous credit experiences. Additional information is only limited to the matter which is unavailable. Whereas, for dealing with "the new comer", banks could review

\footnotetext{
${ }^{27}$ Kasmir. (2015). Dasar-Dasar Perbankan. Jakarta: Rajawali Pres, p. 136-137.

${ }^{28}$ Ismail. (2011). Perbankan Syariah. Jakarta: Kencana, p. 120.

${ }^{29}$ Zubairi Hasan. (2009). Undang-Undang Perbankan Syariah Titik Temu Hukum Islam Dan Hukum Nasional. Jakarta: PT Raja Grafido Persada, p. 199.

${ }^{30}$ Ismail, Loc, cit, p. 121.
} 
by curriculum vitae including educational background, courses, training that have been joined and also the past working experiences. ${ }^{31}$

\section{Capital}

Capital will be considered by banks in terms of determining the eligibility of credit. In the case of granting loans, the Bank requires a limit on the amount of credit compared to certain total capital owned by the debtor. This capital assessment is done by looking at the business capital owned by the customer before getting additional funds when applying for credit. ${ }^{32}$

\section{Collateral}

Collateral is an asset pledged by the debtors to the creditors until a loan is paid back. If the debtors fail to pay, then the creditors have a right to seize the collateral and sell it to pay off the loan. ${ }^{33}$

It's serve as a guarantee that has been given by the debtor to the bank and It could be a physical or non-physical objects. Collateral should exceed more than the amount of the credit that has been given by the bank and should be examined whether it's valid or not. ${ }^{34}$

\section{Economic Situation}

A credit assessment through analysis of the current and upcoming condition of economy, social, and politics. The assessment of the condition of the business which financed should has a great prospect for minimizing the non-performing finance. ${ }^{35}$

Based on these matters, the legal certainty value which contained in this policy has been manifested in various technical-procedural regulations that underlie the implementation of the law, including how to determine credit through the $5 \mathrm{C}$ assessment. The aspect of legal certainty in this policy focuses on putting the two legal subjects, the debtor and creditor, as a part of an economic system that requires a clear and balanced credit mechanism at the time of the outbreak.

\section{The Construction of Legal Utility through Banking Credit Restructuring Policy}

Generally, in provide credit restructuring, banks refer to POJK No.11/2020 for asset quality assessment. However, the implementation of the restructuring scheme can vary and is largely determined by the policies of each bank, depending on the assessment of the profile and capacity of paying debtors.

Restructuring relies on its banks, yet the mechanism and the debtor's assessment also rely on the banks. The POJK No. 11/2020 provides a clear order that the bank should have its own guidelines for explaining the criteria of the debtors whose be appointed as affected debtors and the mechanism of the restructuring process itself.

When discussing the process and achievement of a policy, utility is one of the main issue that will always appear in related discourses. The aspect of legal utility is always related to the ability of a rule or judge's decision and its impact. As Bernstein stated, "the legal utilitarian must

\footnotetext{
${ }^{31}$ Maya Ariyanti, Rachmat Firdaus. (2003). Manajemen Perkreditan Bank Umum: Teori, Masalah, Kebijakan Dan Ap likasinya Dengan Analisis Kredit. Bandung: Alfabeta, p.84.

${ }^{32}$ Ismail, Loc, cit, p. 123.

${ }^{33}$ H. Schutte B. Balkenhol. (2007). Collateral Law, Collateral Substitutions, 2nd edn Geneva: Social Finance Program, Employment Sector International Labour Office Geneva, p. 7.

${ }^{34}$ Kasmir, Op.cit, p. 92.

${ }^{35}$ Kasmir, Op.cit, p. 137.
} 
have a concept of the consequences of an act. It is necessary not only in order to understand the principle that an act is right which has best consequences, but also to compare it with ruleutility". ${ }^{36}$ Thus, the utility of a legal product must be seen not only from the existence of its principles but also on how the act in creating the utility itself.

Related to the practical domain or described by Bernstein as an "act" of the banking credit restructuring policy, the bank will refer to the procedural framework in POJK No. 11/2020 for asset quality assessment. However, the implementation of the restructuring scheme can vary and is largely determined by the policies of each bank, depending on the assessment of the profile and capacity of paying debtors.

The POJK No. 11/2020 instructed that the bank should have its own guidelines for explaining the criteria of the debtors who's appointed as affected debtors and the mechanism of restructuring process on the bank.

OJK noted that until May, 26th 2020, 96 banks had enacted restructuring policy to the 5.33 million debtors with the total value Rp517.2 trillion and 4.55 million MSME debtors with the total value Rp250.65 trillion. ${ }^{37}$

Several banks that has enacted the restructuring policy are Bank Mandiri, Bank Rakyat Indonesia, Bank Negara Indonesia, Bank Pan Indonesia, Bank Permata, Bank BTPN and Bank DBS Indonesia. While Bank Mandiri and Bank Rakyat Indonesia themselves has provide relief to postpone the affected debtors payment. ${ }^{38}$

Bank Negara Indonesia also providing a relaxation policy through this restructuring for the debtors. However, this relief would be adjusted with the form and conditions of debtors business. Bank Pan Indonesia (PNBN) and Bank Permata has provide restructuring policy through extension of the credit period, postpone principal installment payment to the relief for payment of the interest within a period time and requisite which is adjusted with the economic condition of the debtors. ${ }^{39}$

Bank BTPN and Bank DBS Indonesia has specifically mentioned that they will provide a credit relief to the debtors who are informal workers, daily income workers, and micro and small business with the plafon value maximum 10 billion IDR. Another requisite is the debtors don't have any arrears more than 90 days until April 2020 and the relief is provided until 1 year. ${ }^{40}$

Furthermore, OJK recognizes many obstacles in implementing credit restructuring, particularly a technical issue such as face-to-face mechanisms, data verification and debtor condition updates which are the effects of social distancing policies. Moreover, this condition is getting more complicated since banks must continue to pay attention to existing prudential banking principles.

\footnotetext{
${ }^{36}$ Richard F. Bernstein. (1979). 'Legal Utilitarianism', Ethics Journal, 89.(2), 133.

${ }^{37}$ Otoritas Jasa Keuangan. (2020). OJK Terbitkan Kebijakan Stimulus Lanjutan Untuk Mendukung Pemulihan Ekonomi Nasional, Jakarta<https://ojk.go.id $>$, accessed on $29^{\text {th }}$ May 2020.

${ }^{38}$ Husein Mifatudin. (2020). OJK: Banyak Kendala Dalam Restrukturisasi Kredit Covid-19, Jakarta, <https://www.med com.id/ekonomi/keuangan/PNgWaR0N-ojk-banyak-kendala-dalam-restrukturisasi-kredit-covid-19>, accesed on 29th May 2020.

${ }^{39}$ Husein Mifatudin, Ibid.

${ }^{40}$ Otoritas Jasa Keuangan. (2020). Sederet Bank Yang Mulai Lakukan Restrukturisasi Kredit. Jakarta, <https://ojk.go.id>, accesed on $29^{\text {th }}$ May 2020.
} 
However, the main obstacle is the WFH (Work From Home) policy implemented in Indonesia lately. This policy resulted in banks to work harder in verifying debtors who proposed credit restructuring. Another obstacle is the amount of the debtors who applied restructuring isn't comparable with the amount of the bank's employees. This caused a slow process in restructuring service in banks. ${ }^{41}$

Responding to these obstacles, OJK would like to issue a new regulation after identifying the obstacles which are experienced by banks in implementing the restructuring.

OJK has identified several things which gave conveniences to the Banks in implementing this policy. Furthermore, these conveniences will be incorporated into further policies to deal with the impact of Covid-19.42

In encounter of the outbreak, OJK has issued this regulation for helping both debtors and banks. In this regulation, affected debtors are entitled to a restructuring or relief of credit payments with a maximum period of 12 months in accordance with the criteria of each debtor adjusted to the policies of each bank in providing the credit restructuring.

The entire set of rules in this policy is designed to generate utility for the society or both parties. Therefore, the implementation of the act-utility focus on the optimization of intermediation bank function, maintain the financial stability and support the economic stability by provide restructuring to the affected debtors (micro, small, medium enterprise debtors). This regulation is expected to be a solution for both debtors and banks in encountering the financial problem amid Covid-19. Hence, one of the main provisions of the act-utility on this issue is the ability of the government prevent debtors difficulties in paying and cause new problems such as bad loans which will actually reduce the performance and financial problems of banks.

The act-utility of this policy cannot be observed only from the legal realm, but also from the economic sector. Not much different from the discourse that occurs in the construction of justice, the synthesis between rule-utility and act-utility on this policy can be fully realized if this policy constructs a "bridge" of continuity with the conditions after the end of the outbreak or the policy itself.

\section{CONCLUSION}

Based on the research results, two conclusions were obtained to answer the research problem;

First that, banking credit restructuring policy is a legal policy that provided to the debtors who affected by the spread of Covid-19, this policy is implemented to encourage banking performance, mainly related to the intermediation function, maintain financial system stability, and support economic growth and help debtors affected by Covid-19 so that it still meets the credit payment obligations.

Second that, POJK No.11/2020 as a countercyclical policy in the banking credit sector is a legal instrument that tries to create a space for legal justice, certainty, and utility is in the midst of the outbreak. The values of legal justice, confidence, and service, which is at the core of the banking restructuring policy are not only conceptually realized, but also manifests in the

\footnotetext{
${ }^{41}$ FIN. (2020). Restrukturisasi Kredit Belum Optimal. Jakarta <https://fin.co.id/2020/05/20/restrukturisasi-kredit-be lum-optimal/, >, accesed on 29th May 2020.

42 FIN. (2020). OJK Rilis Kebijakan Lanjutan Bagi Bank Dalam Hadapi Corona. Jakarta, https:// finansial.bisnis.com/ read20200519/90/1242574/ojk-bakal-rilis-kebijakan-lanjutan-bagi-bank-dalam-hadapi-corona, accesed on 29th May 2020.
} 
practical-implementation realm by understanding the construction of the three fundamental values, hence, its function perceived by the involved parties.

This research can be carried out and completed so as to produce a journal writing, thanks to the support of various parties. First of all the writer would like to thank the author's parents, for his attention and affection for the author, as well as the Master in Legal Science Program, Faculty of Law, Universitas Gadjah, as a very supportive place in the intellectual development of the writer.

\section{Bibliography}

Books:

Abdul Ghofur Anshori. (2016). Filsafat Hukum Sejarah, Aliran Dan Pemaknaan, Yogyakarta, Gadjah Mada University Press.

David Lyons. (2003). In the Interest of the Governed: A Study in Bentham's Philosophy of Utility and Law. New York: Oxford University Press.

Faudy, Munir. (2005). Filsafat Dan Teori Hukum Posmodern. Jakarta: Kompas.

Ismail. (2011). Perbankan Syariah. Jakarta: Kencana.

Kasmir. (2015). Dasar-Dasar Perbankan. Jakarta: Rajawali Press.

OMill, John Stuart. (1998). Utilitarianism. London: Oxford University Press.

Rachmat Firdaus, Maya Ariyanti. (2003). Manajemen Perkreditan Bank Umum: Teori, Masalah, Kebijakan Dan Aplikasinya Dengan Analisis Kredit. Bandung: Alfabeta.

Rawls, John. (1971). A Theory of Justice. London: Harvard University Press.

Ridwan Halim. (1987). Evaluasi Filsafat Hukum. Jakarta: Ghalia Indonesia.

Rivai, Vaithzal. (2008). Islamic Financial Management: Teori Konsep Dan Aplikasi Panduan Praktis Untuk Lembaga Keuangan, Nasabah, Praktisi Dan Mahasiswa. Jakarta: Kharisma Putra Utama Offset.

Satjipto Rahardjo. (2014). Ilmu Hukum. Bandung: Citra Aditya Bakti.

Soerjono Soekanto, Sri Mamudji. (2001). Penelitian Hukum Normatif; Suatu Tinjauan Singkat. Jakarta: Raja Grafindo Persada.

Sudikno Mertokusumo. (1993). Bab-Bab Tentang Penemuan Hukum. Bandung: Citra Aditya Bakti.

Tebbit, Mark. (2017). Philosophy of Law: An Introduction, New York: Routledge.

Theo Huijbers. (1991). Filsafat Hukum Dalam Lintasan Sejarah. Yogyakarta: Kanisius.

Zubairi Hasan. (2009). Undang-Undang Perbankan Syariah Titik Temu Hukum Islam Dan Hukum Nasional. Jakarta: PT Raja Grafido Persada.

Journal articles:

Ashinta Sekar Bidari, Reky Nurviana. (2020). 'Stimulus Ekonomi Sektor Perbankan Dalam Menghadapi Pandemi Coronavirus Disease 2019 Di Indonesia', Legal Standing Jurnal Ilmu Hukum, 4.1 (2020).

Benuf, Kornelius, and Muhamad Azhar. (2020). 'Metodologi Penelitian Hukum Sebagai Instrumen Mengurai Permasalahan Hukum Kontemporer', Gema Keadilan, 7.(1). 
Depri Liber Sonata. (2014). 'Metode Penelitian Hukum Normatif Dan Empiris Karakteristik Khas Dari Metode Meneliti Hukum', Fiat Justisia Jurnal Ilmu Hukum, 8.(1).

Heather Leawoods. (2000). 'Gustav Radbruch: An Extraordinary Legal Philosopher', Washington Universiy Journal of Law \& Policy, 2.(1).

Herdian Ayu Andreana Beru Tarigan, Darminto Hartono Paulus. (2019). 'Protection of Customers For Management of Digital Banking Services (Study at PT. BRI Unit Boyolali)', Hang Tuah Law Journal, 2.(2).

Prayogo, R. Tony. (2016). 'Penerapan Asas Kepastian Hukum Dalam Peraturan Mahkamah Agung Nomor 1 Tahun 2011 Tentang Hak Uji Materiil Dan Dalam Peraturan Mahkamah Konstitusi Nomor 06/PMK/2005 Tentang Pedoman Beracara Dalam Pengujian Undang-Undang'. Jurnal Legislasi Indonesia, 13.(2).

Richard F. Bernstein. (1979). 'Legal Utilitarianism', Ethics Journal, 89.(2).

Samuel Arsheldon, Supriardoyo Simanjuntak. (2020). Kornelius Benuf, 'Strategi Antisipasi Over Kapasitas Lapas Suatu Refleksi Atas Kebijakan Pencegahan Penyebaran Covid-19', ADLIYA: Jurnal Hukum Dan Kemanusiaan, 14.1.

Sutanto, Himawan, Hanif Nur Widhiyanti, and Istislam Istislam. (2018). 'Legal Protection Against Banks As A New Creditural Candidate In Take Over Credit Process', Unram Law Review, 2.2

World Wide Web:

B. Balkenhol, H. Schutte. (2007). Collateral Law, Collateral Substitutions, 2nd edn, Geneva: Social Finance Program, Employment Sector International Labour Office Geneva.

FIN. (2020). OJK Rilis Kebijakan Lanjutan Bagi Bank Dalam Hadapi Corona. Jakarta.

. (2020). Restrukturisasi Kredit Belum Optimal <https://fin.co.id/2020/05/20/ restrukturisasi-kredit-belum-optimal/,>

Gugus Tugas Percepatan Penanganan Covid-19, (2020), Situasi Virus Covid-19 Di Indonesia, https://doi.org/DOI: http://dx.doi.org/10.30649/htlj.v3i2.128

Husein Mifatudin. (2020). OJK: Banyak Kendala Dalam Restrukturisasi Kredit Covid-19. $<$ https://www.medcom.id/ekonomi/keuangan/PNgWaR0N-ojk-banyak-kendaladalam-restrukturisasi-kredit-covid-19>.

Organization, World Health. (2020). Coronavirus Disease (Covid-19) Situation Report-121, $<$ https://www.who.int/emergencies/diseases/novel-coronavirus-2019/situationreports $>$

Otoritas Jasa Keuangan. (2020). Frequently Asked Questions: Restrukturisasi Kredit Pembiayaan Terkait Dampak COVID-19.

. (2020). OJK Terbitkan Kebijakan Stimulus Lanjutan Untuk Mendukung Pemulihan Ekonomi Nasional. Jakarta. <https://ojk.go.id> . (2020). Sederet Bank Yang Mulai Lakukan Restrukturisasi Kredit. $<$ https://ojk.go.id $>$ 